THOMASP. JOHANSEN

\section{Håndens værk}

Glenn Adamson (red.): The Craft Reader, Berg, Oxford, 2010, 642 sider, f24.99.

Glenn Adamson har med The Craft Reader samlet 76 uddrag fra tekster som på vidt forskellige måder drejer sig om håndværket. Hermed leverer Adamson en sand guldmine til inspiration for den, som ønsker at bevæge sig ind i et emne, der siden slutningen af 1800-tallet har udgjort et betydningsreservoir for både kultur- og samfundskritikken, kunsten, pædagogikken/ didaktikken og filosofien. En af genistregerne hos Adamson er i al sin enkelthed, at hans udvalg er begrænset $i$ tid netop ved at definere 'modern craft' som et problem, der ikke opstår før industriens afløsning af håndværket som primær produktionsform. Det gav for eksempel ingen mening i 1600-tallet at sælge sko ved at fremhæve at de var håndlavede. Hvordan skulle ellers være lavet? Feministiske bevægelser, antikapitalistiske DIY (do it yourself) bevægelser, back to basic tendenser i samtiden samt kommercielle strategier som storytelling, alle trækker de på den autenticitet som håndværket emmer af. I en gennemmedieret verden anno 2010 hvor alting, qua den medierede fremtræden, kan synes nært på en uendelig fjern måde, består håndværkets fascinationsevne måske netop i det element af xgte nærhed til kroppen, som er uløseligt forbundet med dets idé.

Tidligere har man beskrevet håndværkets (eller et specifikt håndværksfags) kulturhistorie helt klassisk, med storhedstid omkring lavsvæsnets dannelse og frem til begyndelsen af det 19. århundrede, hvorfra en lang forfaldsproces tager til i takt med industrialiseringens fremmarch. Herefter er håndværket parkeret $i$ en underafdeling af kunsten eller af luksusindustrien. En af konsekvenserne ved denne optik er, at håndværket blot bliver en adspredelse, som vi kan ty til, når vi ellers har livsfornødenhederne på det tørre. Inden for de sidste år er der imidlertid kommet et fornyet syn på håndværket. Et syn som forsøger at hæve sig over den nostalgi og konservering som har præget den tidligere litteratur. Man begynder nu at anskue håndværket som en almen menneskelig praksis. Et eksempel på dette er Richard Sennett, hvis bog The Craftman (2008) udkom på dansk i 2009. I indledningen til The Craft Reader fremgår det klart, at det er med denne nye udvidede tilgang til håndværket, at samlingen skal læses.

Antologien består både af såkaldte primærtekster og sekundær- 
tekster. Disse er opdelt i syv afsnit, arrangeret $i$ en heldig blanding af kronologi og tematik. Hvert afsnit er forsynet med en kort introduktion, som på elegant vis forbinder hver enkelt afsnit med de foregående, således at der hele tiden bliver redegjort for perspektivændringens relevans og sammenhæng i et større billede. Dette er yderst vellykket, og Adamson får med sine introduktioner på forbilledlig vis gjort lige præcis det, som en god redaktør kan og skal: Han løfter teksterne ved at levere en kontekst, som gør hver enkelt tekstuddrag relevant. Yderligere er der også ved hver enkelt tekst skrevet cirka halvanden spalte præsentation af teksten og tekstens forfatter. De syv afsnit dækker så vidt forskellige aspekter som håndværkets forhold til dannelsen, til maskinerne, til kunsten, til kunstinstitutionen, til modkulturer og til menneskets væren i verden. Dog ligger hovedvægten på trianglen: kunst, håndværk, livsform.

Afsnittene er arrangeret således, at de tre første afsnit: "Howto", "Craft and the Industrial Revolution" og "Modern Craft: Idealism and Reform", indeholder tekster, som først og fremmest er eksempler på hvordan håndværket på forskellige måder er blevet brugt i forskellige sammenhænge, under udviklingen af industrialiseringen og det moderne samfund over- hovedet. Det er i disse tre forste afsnits tekster, at vi finder modstillingen af håndværk og modernitet tydeligst artikuleret. Disse afsnit indeholder bidrag af blandt andre sløjdens fader Otto Salomon, politiske og økonomiske tænkere som Alexis de Tocqueville og Karl Marx, arkitekterne Frank Lloyd Wright og Adolf Loos og Arts and Crafts bevægelsens ophavsmænd John Ruskin og William Morris. Særligt de sidstnævnte spiller en stor rolle for resten af antologien. I præsentationen af Morris' tekst "The revival of handicraft" skriver Adamson: "Much of this book, The Craft Reader, is an attempt to recontextualize his [William Morris'] Arts and Crafts ideal and its attendant contradictions by emphasizing other approaches to the subject." (s. 146) Herved afsløres Adamsons hovedinteresse, nemlig håndværkets forhold til den moderne kunst. Udvalget præsenterer en fin blanding af både fortalere for og kritikere af maskinernes indtog i produktionen. I det hele taget nuanceres den ellers traditionelle opfattelse at håndværkets antagonistiske position i forhold til industriel maskinproduktion. Snarere må håndværket ses som direkte involveret i udviklingen. Man kan for eksempel læse i Samuel Smiles' "Industrial Biography: Iron Workers and Tool Makers" (1863), hvor- 
dan Watts og Boultons udvikling af dampmaskinen kan ses som en opvisning $\mathrm{i}$ fremragende håndværksmæssighed.

I de næste tre afsnit "The Persistence of Craft in the Age of Mass Production", "Craft in Theory: Aesthetics, Essence, Status" og "Craft in Action: Life, Art, Design" flytter fokus sig over på håndværket som almenmenneskelig aktivitet. Dette sker $\mathrm{i}$ takt med, at teksterne nærmer sig nutiden. Her finder vi tekster om Cybernetics ved Norbert Wiener, en artikel om Walter Benjamin, tekster af Theodor Adorno (fra "Funktionalismus Heute") og Martin Heidegger ("Das Ding") og manifester fra Bauhaus. Hvor forceret det end kan virke at plante Benjamin, Adorno og Heidegger i afsnittet "Craft in Theory", får Adamson alligevel sandsynliggjort deres tilknytning til emnet. Anderledes forbavsende er det, at man i denne antologi leder forgæves efter Hannah Arendt. Med hendes skelnen mellem 'arbejde' og 'fremstilling' synes hun i langt højere grad end hendes tre ovenfornævnte samtidige landsmænd at give en perspektivrig vinkel på håndværket. Den eneste gang hun er nævnt er desværre i Adamsons præsentation af Esther Leslies tekst om Benjamin, hvor Arendt lidt klodset bliver anført som et medlem af Frankfurterskolen. En bås hun næppe selv ville være tilfreds med at blive sat i, og som i øvrigt ikke beskrives med meget andet end adjektiverne: jødisk og marxistisk (i den rækkefølge).

Det syvende og sidste afsnit "Contemporary Approaches", indeholder en lille håndfuld dugfriske tekster, som skal give os et hint om, i hvilken retning håndværket bevæger sig her i starten af det 21. århundrede, og som sjovt nok alle er skrevet af kvinder. Tilsyneladende har håndværkeren skiftet køn over de sidste snart 200 år. To tendenser bliver præsenteret: En politiserende tilgang (craftivism) og en postdisciplinær tilgang. Heraf vægtes den sidste højest. Begge tilgange er så at sige børn af Arts and Crafts tankerne; den første ved sin idealisme; den sidste ved forsøget på at ophæve adskillelsen mellem håndværker og kunstner.

En antologi som The Craft Reader der indeholder over 70 tekster fordelt på godt og vel 600 sider, kan i sagens natur ikke tilbyde meget andet end appetitvækkere. Tekstuddragene er meget korte, men de er til gengæld, for langt størstedelens vedkommende forsynet med minimum tre til fem henvisninger til videre læsning, ud over den tekst uddraget er taget fra.

Tilbage er blot at anbefale denne glimrende antologi til alle med interesse for forholdet mellem 
kunst og produktion ved overgangen fra det 19. til det 20. århundrede og op til i dag - eller simpelthen bare for håndværket som kulturelt fænomen.

MARTIN SKOVBJERG JENSEN

\section{Religiøsitetens rolle efter folkemord}

Thomas Brudholm \& Thomas Cushman (red.): The Religious in Responses to Mass Atrocity: Interdisciplinary Perspectives, Cambridge University Press, 2009, 296 sider, f45.

I forlængelse af en konference på DIIS i 2006 er 10 bidrag blevet samlet til en antologi om det religiøses rolle over for "mass atrocities" (i det følgende ordret oversat til masse-grusomhed). Ideen med konferencen var at bringe en række discipliner sammen i overvejelserne om, dels hvilken rolle det religiøse deskriptivt kan siges at have spillet og spille, samt også hvilken rolle det bør spille efter folkemordet. Det drejer sig altså ikke om overvejelser om religiøse aktørers eventuelle medansvar for sådanne uhyrligheder, selvom problematikken flere gange bliver nævnt, men i stedet indskriver antologien sig som et intersubjektivt bidrag til feltet "transitional justice". Antologien bliver indledt af udgiverne Thomas Brudholm og Thomas Cushman, hvorefter bidragene er opdelt $i$ tre dele. Bogen er desuden udstyret med et glimrende stikordsregister.

Første del beskæftiger sig med spørgsmålet om, hvilken rolle religiøs sprogbrug burde spille over for masse-grusomheder og består af tre bidrag. Det forste af Jennifer L. Geddes er en glimrende introduktion til problemstillingen, idet det forsøger at komme den religiøse sprogbrug nærmere. Til dette formål foreslås en skala til indordning af, hvilken rolle sådanne ytringer spiller efter en masse-grusomhed har fundet sted. Hun argumenterer for, at vi ikke på forhånd bør afskrive det religiøse sprog som irrelevant, da det både kan kaste lys på begivenhedernes ekstremitet og spille en pragmatisk rolle. Den førstnæunte funktion tjener sproget, når det tilnærmer sig hendes skalas ene ekstrem, den "apophatiske" rolle, i hvilken sprogets åbenhed imod det, som ikke kan ytres i sproget, berøres. For såvel overlevende som akademikere vil det dog være uilfredsstillende blot at konstatere, at noget ikke kan formuleres i sproget, da man på trods af den tilsyneladende umulighed, også ligger under for nødvendigheden af forsøget. Denne situation kendetegner Geddes med det psykologiske begreb "double 